\title{
Methods and Tools for Enabling Employees to Contribute to Technological Progress
}

\author{
http://dx.doi.org/10.3991/ijep.v6i3.5779 \\ Maja Jeretin-Kopf ${ }^{1}$, Claas Christian Wuttke ${ }^{1}$, Rüdiger Haas ${ }^{1}$ and Christian Wiesmüller ${ }^{2}$ \\ ${ }^{1}$ University of Applied Sciences Karlsruhe, Germany \\ ${ }^{2}$ University of Education Karlsruhe, Germany
}

\begin{abstract}
This paper introduces an interdisciplinary continuing professional development concept aiming at providing engineers and technicians with the appropriate skills to foster the Simultaneous Working \& Learning programs (SWLP) in their enterprises. It is furthermore shown, how the need of qualification for the technical personnel can be detected using internal and external sources. In addition the derivation process of individual qualification needs for each employee depending on his function and position in the companies' organization is demonstrated. For each of the above mentioned task appropriate tools are proposed.
\end{abstract}

Index Terms - educational methods and tolls, individual qualification needs, simultaneous working \& learning program, technological progress

\section{INTRODUCTION}

The 'fourth industrial revolution' is an umbrella term representing accelerated technological development, especially in the field of automation, data collection and processing as well as manufacturing. In their concurrence, these single developments allow for creating completely new applications and corresponding business models. The fourth industrial revolution will change not only technological processes but also production itself. In concordance with other socio-economic and demographic changes, it will transform labor markets within the next five years, prompting a net loss of over 5 million jobs in 15 major developed and emerging economies [1]. In order to qualify the employees for retaining their jobs and enable companies to remain competitive, it is necessary to focus on lifelong educational issues.

The small and medium-sized enterprises are the driving force in the German industry. It is expected that, in Germany until 2025, nearly a million of jobs in the professional fields will undergo change. In particular, occupations in the manufacturing sector will be most affected by the job cuts [2]. A majority of businesses now believe that investing in skills is the key factor in successfully managing changes in labor market [1]. Moreover, it is assumed that investing in re-skilling current employees is the best strategy to deal with the current industrial development. The main non technological skills considered to be required in 2020 are complex problem solving, critical thinking, creativity, people management and coordinating with others. The problem is that small and mediumsized companies do not have their own training department, and engineers or technicians rarely have the qualifications for lifelong technology education (LTE).

In view of this development, appropriate education concepts are required for continuing professional devel- opment (CPD) inside the field of technological education. Such a concept has to take into account the requirements of the enterprises as well as the needs of the employees [3]. Customized concepts have to be developed for companies. Concepts such as Simultaneous Working \& Learning programs (SWLP) have to target the understanding of the social, economic and cultural changes happening in the globalized world, and have to adopt new, creative attitudes towards technology and technological progress.

The idea of "Lernfabrik 4.X" aims at realizing such an educational concept and developing SWLP to improve the skills of employees in manufacturing companies. The theoretical framework of the "Lernfabrik 4.X"-Programm focuses on following issues:

1. Which new technologies drive the technological progress in manufacturing companies?

2. Which instructive methods and tools can support the technology and design education inside the SWLP?

3. In which way can SWLP be implemented in manufacturing companies?

Courses have been developed for engineers and technicians on the basis of this theoretical framework, where while on the job, they can expand their knowledge and experience, and earn a certificate in technology and design education.

With the academic background acquired on the educational issues concerning lifelong education concepts, engineers and technicians can impact developing SWLP within their own company, and learn how to transfer the knowledge about production processes and systems to their workers. They are thus able to build a bridge between research and industry, and obtain the required competencies for attending to employees keeping up with the technological progress.

\section{IDENTIFICATION OF RELEVANT TECHNOLOGIES}

The starting point of all strategically and technologically oriented employee qualification is the identification of relevant technologies. One technology that is supposed to significantly change the planning and operation of production systems and design process is Industry 4.0 [4] - also called Industrial Internet [5] or Smart Industry [6], which can be described as the coaction of physical machinery and devices with networked sensors and software, used to predict, control and plan for better outcomes.

While Industry 4.0 consists of a bundle of increasingly significant technologies, spanning various classes of businesses - according to a concurrent appreciation of experts, there are also many other technologies in material science, 
manufacturing, as well as new planning and management methods, such as lean management or agile development, that will influence industrial work in a more or less profound way. The topics which influence the competitiveness of workers and employees as well as enterprise itself, are not limited to the above-mentioned technologies. In fact, other trends and topics might be more or less relevant, e.g. sustainability with all its aspects in production and engineering, as well as lean production and lean management. Besides the right attitudes, employees and workers need the concrete methods and tools for implementation in their fields of responsibility and operation.

Thus for each enterprise, it has to be defined which abilities and know-how of personnel are relevant. Furthermore, their degrees of priority have to be specified. The methods and tools of the technology management [7] can be applied to perform these tasks. With regard to the width of the perspective, three successive procedures can be identified [8]:

- Scanning

- Monitoring and

- Scouting

Scanning consists of superficially observing a wide range of sources of information. In the first stage, no restrictions are made, while in the second stage, some issues might be of special interest. Scanning is a continuous process. The following monitoring is induced by the prior identified issues providing the restrictions for the following search. In case of more detailed need for information e.g. to prepare the abovementioned migration of technologies into the enterprise, the phase of technology scouting can be added [9]. Its goal is the obtaining and preparation of specific knowledge, e.g. know-how regarding the application of technologies in the branch of the enterprise conducting the search.

Table I presents an overview of the phases of technology intelligence, and shows which people are integrated in each case. Furthermore, examples of media and other sources of information are named using [8-11].

While Table I only delivers some examples of the sources and media used for technology intelligence, Table II presents a structured list of sources for identifying the relevant technologies, using $[8,11]$.

Table II also shows that there a lot of external sources for the identifying and ranking of the external sources. These are mainly involved in the scouting and monitoring of new technologies and topics. Involving external partners in an innovation processes is an extensive action. Furthermore, it implies certain risks. In [12] a feasible method for the systematical integration of customers in innovation processes is presented, including a list of methods, which are detailed in [13].

To support the adaption of the methodology presented in $[12,13]$, the authors recommend using the matrix shown in Figure 1. Not all partners that can be integrated in the technology intelligence process have the significant expertise and experience in all technologies and topics. These correlations are analyzed and visualized in a matrix that is documented. It shows all relevant technologies and topics on one axis, and all possible external partners in the others. In this way, it is possible to assign each partner to one or more interesting technologies. In the case of redundancies in expertise and experience, partners with only
TABLE I.

FORMS OF TECHNOLOGY INTELLIGENCE IN SME

\begin{tabular}{|c|c|c|}
\hline Stage & Men of action & Media/Sources, e.g. \\
\hline . & $\begin{array}{l}\text { All managers and skilled } \\
\text { employees }\end{array}$ & $\begin{array}{l}\text { Business press and specialized } \\
\text { journals } \\
\text { Informal contact to customers, } \\
\text { suppliers } \\
\text { Information of trade associa- } \\
\text { tions }\end{array}$ \\
\hline 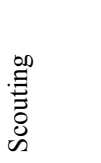 & $\begin{array}{l}\text { Selected managers and } \\
\text { skilled employees }\end{array}$ & $\begin{array}{l}\text { Specialized Journals } \\
\text { Contact to external partners } \\
\text { related to a special field }\end{array}$ \\
\hline Stage & Men of action & Media/Sources, e.g. \\
\hline \multirow{4}{*}{. } & $\begin{array}{l}\text { Selected managers and } \\
\text { skilled employees }\end{array}$ & Specialized Journals \\
\hline & $\begin{array}{l}\text { External experts and } \\
\text { organizations }\end{array}$ & $\begin{array}{l}\text { Contact to external partners } \\
\text { related to a special field } \\
\text { Patent holders }\end{array}$ \\
\hline & & Competitors \\
\hline & & Experts \\
\hline
\end{tabular}

TABLE II

SOURCES FOR IDENTIFYING RELEVANT TECHNOLOGIES

\begin{tabular}{ll}
\hline Internal sources & Product development \\
& Manufacturing process development \\
& Production, Logistics und IT \\
& Marketing and Sales \\
\hline Public external sources & Patents \\
& Public and specialist publications \\
& Internet \\
& Competitors \\
\hline Closed external & Industrial federation \\
sources & Contracting enterprises \\
& Suppliers \\
& Customers \\
& Experts \\
\hline
\end{tabular}

limited potential to support the intelligence process can be ignored, in order to simplify the handling of the technology intelligence process.

Results of this work are:

- A list of prioritized technologies relevant for the enterprise

- A structured description of the technology, including links to further information and partners

- Detailed information for prioritized technologies as a basis for training material

The selection and prioritization of technologies represent an implicit technology strategy for the company. It defines the fields the company seeks for a fast adoption, or even a technological leadership. Considering the restricted resources of any company, it is not possible to aim for leadership in all fields. The above-described process of technology intelligence and planning has to be repeated in a more or less intensive way, depending on the technological progress or change of corporate strategy. 


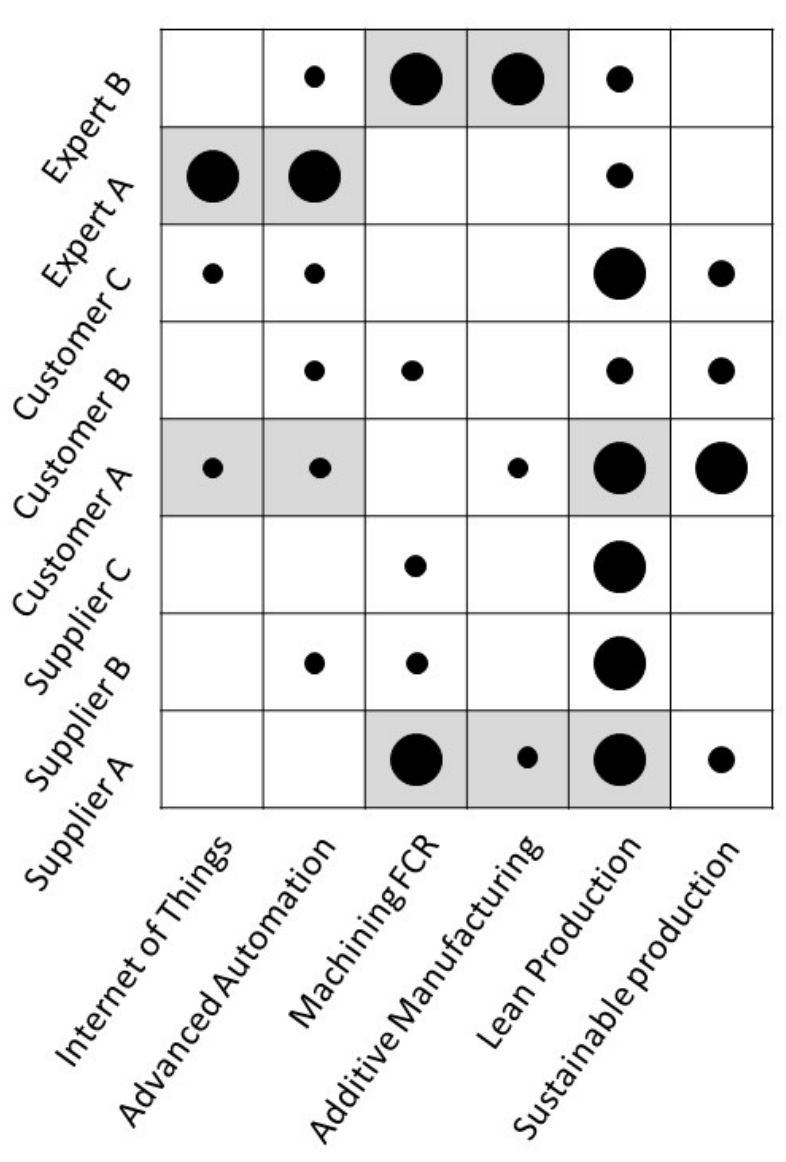

Minor expertise / experience

Significant expertise / experience

Request to support

Figure 1. Know-how matrix of external partners assigned to a special partner

\section{EDUCATIONAL APROACH}

In response to the challenges of technology and business development, there have been a wide range of analyses in Europe underlining the importance of lifelong education [14], in which developments in knowledge, skills and competences (KSC), and innovation all seem to reinforce each other [14]. Thus, one of the most crucial strategies for lifelong learning is the learning at the workplace [15]. Cedefop analyzed the educational strategies of several enterprises, and concluded that company training has been strongly focused on the daily functioning of employees in the workplace [15], so that any subordinate educational goals are not taken into account. There is a gap between daily needed skills and the subordinate general KSC, which has to be bridged if companies want their employees to contribute to technology development. The Cedefop study emphasizes the need for addressing the quality of training provided to companies, as well as the competencies of trainers [15]. So what competencies do trainers have to acquire in order to provide for learning at the workplace? The educational concept of "Lernfabrik 4.X" defines four bridge stones for teaching educators in

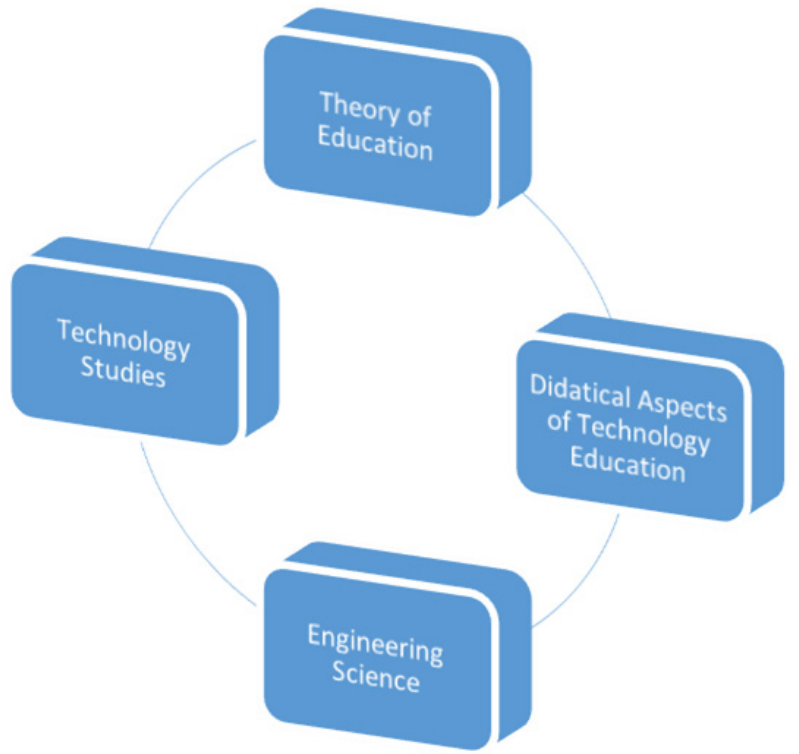

Figure 2. Essential elements of the "Lernfabrik" concept

manufacturing companies. The first, the theory of education, includes pedagogical issues that address lifelong learning, the designing of educational contexts, and motivational aspects. The second focuses on the didactical aspects of technology education, providing the trainers with the competencies that enable them to analyze educational needs, develop applied curricula, and design a learning process for the employees. The third includes engineering science, where participants learn to identify the technologies relevant for the further business development of their company. The fourth bridge stone, technology studies, addresses the philosophical and anthropological aspects of technology.

In this paper, we focus on the didactical aspects of technology education.

\section{A. Didactical Aspects of technology education: A} multiperspectival approach (MpA)

An understanding of the main subject, technology education, requires a clear definition of technology. In spite of the fact that the meaning of the term "technology" has undergone several changes in the past [16], there seems to be an agreement in German philosophy of technology, on "technology" as a generic term for

- "practices of the development and production of technology,

- practices in which technology is employed, and for

- practices in which technology is withdrawn from its context of use" [17].

Technology in this sense is complex and dynamic, so that a deep understanding (knowledge and awareness) of technology requires taking into account several attributes, characterizing the individual background, that makes the understanding possible. These attributes can be described as (1) the relationship between the human being and the world surrounding him, (2) the voluntary attitude towards the world's exigencies, (3) one's skills and competencies, and (4) the emotional and cognitive disposition toward the nature and technology $[18,19]$. 
Technology education in Germany has already had a long tradition, and different concepts of "Technikdidaktik" have been developed. Didactical approaches describe the way how to reach an educational goal, in this case the understanding of technology. The concept that mostly focuses on "Bildung", as the continuous development of a person as an individual is understood, is the socalled Multiperspectival Approach (MpA) [19-24]. MpA claims that technology education has to take into account three perspectives:

(1) Education is to be seen as a process that focuses on personal, individual development. (2) A human being has to be understood as the creator of his culture on the one hand, and as a product of his culture on the other. Moreover, (3) the concept of the deeper meaning and ethical aspects of human practices has to be comprehended if technology education is to enable students to understand technology and to contribute to the further development of technology and culture.

Educational settings are structured by the educational goals, educational content and educational methods that are defined in advance. Learning does not simply happen, it has to be staged. Its context, purpose, and value create a context in which issues, challenges and topics arise. Coping with them enables the student to develop skills and competencies that are acquired, and to participate in technology development.

\section{B. Educational goals of technology education}

The superordinate goals of technology education are not limited to school or high school education in the sense that lifelong learning goals have to be defined, which also have their validity also in the quaternary education.

Schmayl [22] describes two different types of educational goals, the first is object-oriented and focuses on the entity of artefacts, and the second is person-oriented, and focuses on the person, i.e. the individual to be educated.

Object-oriented goals pursue the three different dimensions of: (1) expertise and objectivity, (2) socio-technical insight and capability, and (3) ethical awareness and responsibility [22].

Person-oriented goals pursue the three different dimensions of: (1) ability and skills, (2) knowledge and understanding, and (3) individual attitudes [22] (Table III).

The above goals are the pillars of technology education. They are fundamental for the further development of learning goals in a concrete educational setting. A successful technology education requires a holistic approach that takes all these into account. In the last decades, technology education has been closely linked to education in science and mathematics [25, 26], where the personal, social and ethical issues of technology were often excluded. If companies want to quit developing technology, this paradigm will have to undergo a change.

\section{Developing curricula for formal educational settings inside the company}

Formal education can be described as essentially curricula-driven. It usually takes place in schools or universities, and has a defined content [27]. Inside companies, trainings take place in formal and informal settings. Formal education is often carried out by private education providers and it focuses very closely on the required knowledge and skills necessary in a very specific work
TABLE III.

SUBORDINATE GOALS OF TECHNOLOGY EDUCATION

\begin{tabular}{|l|l|}
\hline \multicolumn{1}{|c|}{ Object-oriented goals } & \multicolumn{1}{|c|}{ Person-oriented goals } \\
\hline $\begin{array}{l}\text { Expertise and objectivity } \\
\text { Socio-technical insight and capa- } \\
\text { bility } \\
\text { Ethical awareness and responsibil-- } \\
\text { ity }\end{array}$ & $\begin{array}{l}\text { Ability and skills } \\
\text { Knowledge and understanding } \\
\text { Individual attitudes }\end{array}$ \\
\hline
\end{tabular}

place [28]. This means that curricula have to be written in accordance to the specific needs of the enterprises. They should take into account the qualifications of the employees, and the individuals' continuing professional development plan. In order to develop such curricula for formal educational settings inside the company, the executive professionals should themselves not only have the knowledge about the technologies, they should also be able to define the goals and the content of the education, while at the same time taking into account the individual needs of the employees.

\section{Taking into account the informal educational settings}

Besides formal training, there are a lot of informal educational settings inside the companies, where the employees gain new knowledge and acquire new skills that are usually not organized by the employers. The employees themselves organize this learning process, and themselves define what and how they want to learn. The winning point of this kind of learning is the fact that the employees involved in the working process can thus define their needs as they occur. Focusing on the working process means that they have a very narrow view of just-in-time requirements. But focusing on just-in-time requirements means that, generally, subordinate goals are often excluded.

To promote both, the subordinate goals of technology education and the just-in-time requirements, enterprises have to develop curricula that define the educational framework and establish a learning culture that sustains informal education.

\section{E. Didactical methods fostering technology education}

Didactical methods aim to structure the learning processes. They divide the lecture into sections in which students can achieve very specific learning outcomes. Schmayl [cf. 22], in accordance with Wilkening [29], has defined a number of didactical methods for technology education, which he arranged according to object-oriented goals and person-oriented goals. He also divided them into those which foster active and productive learning processes, in which the learner generates knowledge, and those where the student is being instructed, where the learning process itself is generally passive. In Table IV, the didactical methods are presented in Schmayl's order, in slightly adapted way.

These methods have been developed and structured for the purpose of technology education in primary and secondary schools. Nonetheless, they may also be adapted and adjusted for tertiary and quaternary education.

Specifically, the object-oriented methods that foster all kinds of hands-on activities, problem-based or researchbased learning, have already proved themselves as reliable and successful from primary school to high school [30, 31]. Nevertheless, an overview of the literature allows the premise, that in formal education, the companies' problem 
TABLE IV.

DIDACTICAL METHODS FOR TECHNOLOGY EDUCATION [22]

\begin{tabular}{|l|l|l|}
\hline & \multicolumn{1}{|c|}{$\begin{array}{c}\text { Problem or research- } \\
\text { based }\end{array}$} & \multicolumn{1}{|c|}{ Instruction-based } \\
\hline $\begin{array}{l}\text { Object- } \\
\text { oriented }\end{array}$ & $\begin{array}{l}\text { Experiment } \\
\text { Design task } \\
\text { Manufacturing task } \\
\text { Maintenance task } \\
\text { Recycling task }\end{array}$ & $\begin{array}{l}\text { Training/course } \\
\text { Product analysis }\end{array}$ \\
\hline $\begin{array}{l}\text { Person- } \\
\text { oriented }\end{array}$ & $\begin{array}{l}\text { Project } \\
\text { Learning by example }\end{array}$ & Exploration \\
\hline
\end{tabular}

or research-oriented methods are not very common, and the instruction-based courses prevail.

When we realize that didactical methods foster very specific cognitive outcomes, then the question arises, what do we miss if we focus our educational efforts only on instructing students and by letting them acquire theoretical knowledge. Experience with employees in manufacturing companies shows that insufficient theoretical knowledge is not really the problem. Moreover, problems arise because there is a gap between the knowledge of "knowing that" and "knowing how" in different contexts. On the other hand, management complains about the lack of creative problem-solving skills by professionals in the construction and the production departments.

So what can be done to deal with this problem? We have to search for didactical methods that foster both the problem solving aspect by applying the knowledge to new situations and contexts, AND the technical creativity aspect. Instructional object-oriented methods would be a poor tool here if we want to reach this goal.

Project learning and learning by example are two person-oriented and problem-based methods that meet these requirements. Both methods are suitable for gaining additional skills and knowledge, fostering understanding and developing individual attitudes towards the learning process. These methods are not new, and they are welldescribed by the literature $[32,33]$. What is new, is the approach to implement them in the learning culture of the companies.

\section{F. Fostering creativity}

Creativity seems to have an impact on the personal development of individuals, as well as on the innovation and economic success of enterprises. Despite its importance, technical creativity hasn't received much attention in technology education. One reason for this may be the difficulty that we have in trying to define what creativity is; there exists a wide range of definitions [34]. As Sawyer points out, creativity can be defined, for example, as a "new mental combination that is expressed in the world" [35], or as a "generation of a product that is judged to be novel and also to be appropriate, useful, of valuable by suitably knowledgeable social group" [35]. According to the Munich model of giftedness and talent described by Heller, technical creativity is seen as a talent factor, as a predictor for giftedness [36]. Heller describes technical creativity as ability to develop technical solutions, and to vary and present them [37]. In the educational context, the point of interest is not so much the capability of being creative, it is moreover the performance, the creative behavior, and its results. Jeretin-Kopf \& Kosack defined the person-related and object/material-related aspects of technical creativity [38], both of which have an impact on problem-solving ability. Different aspects of personality, such as interest, persistence, and purposefulness, can be seen as person-related aspects, as well as the ability of recognizing problems, and taking diverse solutions into account. Both of these aspects of personality, and the problem-finding and solving capability, occur during an action. To foster creativity, students or employees must engage in activities that support these capabilities.

What kind of activities can provide this? The following example will illustrate it. Designers of a company were developing ventilation grills that were time-consuming and expensive to produce. The production plant was separate from the design office, so hardly any conversation took place. The problem was that the design engineers, out of lack of knowledge of manufacturing technologies, did not even take alternative solutions into account. Recognizing this, the management asked for an educational program, which was then developed according to the needs required. It addressed both groups, the engineers and the machine operators, and can generally be described as follows: In this program, participants work together, taking several courses. Knowledge about the manufacturing technologies is exchanged, as well as of the technological requirements of the product. Working on real, applied models, the participants together search for different solutions, discuss them, and reflect on the learning process itself. The important part of these courses are the reflections on their own attitudes toward work, technology development in general and in their companies, as well as on their impressions and emotions. Formal and informal educational settings can be combined, and the participants can choose what tools they want to use to proceed with the problem.

SWLP makes sure that the issues to be solved are applied in the learning session, are derived from practice, and that the solutions discussed can be implemented in the company by the employees that have created the issues. SWLP does not mean that learning and working happens at the same time - it means that learning and working focus on the same issues, having the same content. What differs is, the context in which the problems have to be solved. The participants have a very active role in this learning process. But there is still a need for a trainer, a mentor, one who organizes and structures the educational settings. The trainer or mentor can be an employee of the company, an engineer or technician who has gained the required competencies.

\section{IMPLEMENTING SWLP IN MANUFACTURING COMPANIES}

\section{A. Barriers and requirements for implementation}

While implementing the training process, the responsible persons will face several barriers:

- Because of the high standard of efficiency necessary to run a production site in an industrialized country, workers and employees do not have much time to get trained or train themselves.

- Even if the coaching of new employees is a continuously performed task in industrial enterprises, even specialists and managers are normally not provided with professional methods to do so. This leads to inefficient training processes. 
- The requirements for new qualifications is not obvious for most employees and workers because they have not been involved in the detection process for new technological challenges.

For facing these challenges, the efficient implementation of all staff training is built on seven columns:

1. Detailed planning and controlling of the necessity of qualification for all units, down to the single worker or kind of worker,

2. Transferring this plan via the target-evolving process for all managers,

3. Broad visualization of the qualification plans, including the current status of attainment,

4. Tracking the training by periodical checks an personal presence,

5. Providing the instructors with adequate educational skills

6. Install tandems of employees to train each other depending on the complementary qualification needs sufficient for a unit,

7. Using multimedia.

The points are listed in a chronological and logical sequence. For distinguishing their particular leverage on the effort, three of them are described in more detail: The most relavant point of all - providing the acting people with educational skills - has been described in the previous chapter, and the first and the last point are specified below.

\section{B. Application of multimedia}

Driven by the digitalization of workflows and processes, more and more information is available in digitalized versions [11]. In addition, the number of computers, especially mobile computers for professional use, is continually increasing. Their broad utilization in private environments enables almost any person to handle these devices [11]. In [39], it is shown how tablet computers can support the training workflow by providing electronic learning tools, crop drawings, web content, animation and videos, and so on. Tablet computers offer another advantage: these devices are very popular also in private environments, and the handling is similar to that of smartphones, so almost all employees are able to handle them.

\section{Planning and controlling of the qualification process}

Finally - in the first in combination with the third point - the planning and the controlling of the training process is of high importance, and requires methodical support. Only by performing detailed planning, can it be ensured that an adequate qualification profile is provided to each employee. This is not only required for the efficiency of the process; the confirmability of the individual qualification plans helps to motivate the people to be trained as well as the people doing the training.

In a first step to implement the plans, the need identified for additional qualification is derived out of the above-explained technology intelligence process. Next, the management has to decide which unit needs which specific qualification. Figure 3 shows a matrix for qualification planning that supports this planning stage.

As mentioned above, it is necessary to define the need for the qualification of each employee - or group of employees - in bigger companies. Depending on the size of

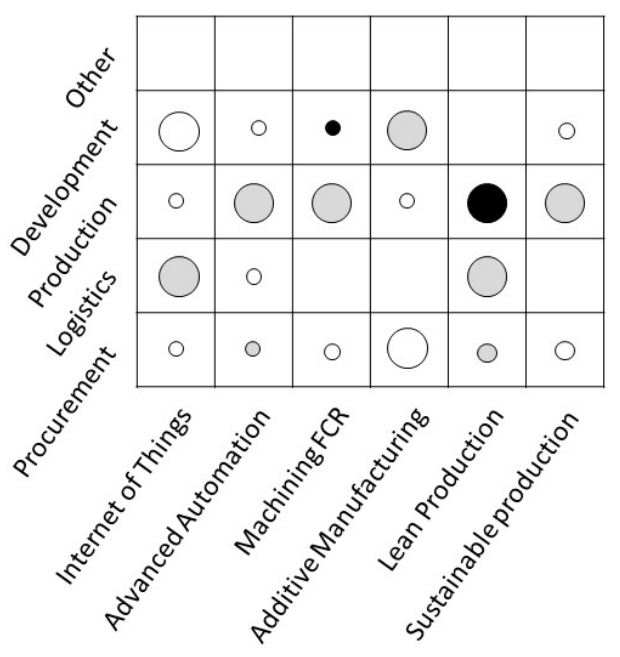

- Minor expertise / experience necessary

Significant expertise / experience neccessary

Training in Progress

expertise / experience proofed

Figure 3. Matrix for qualification planning
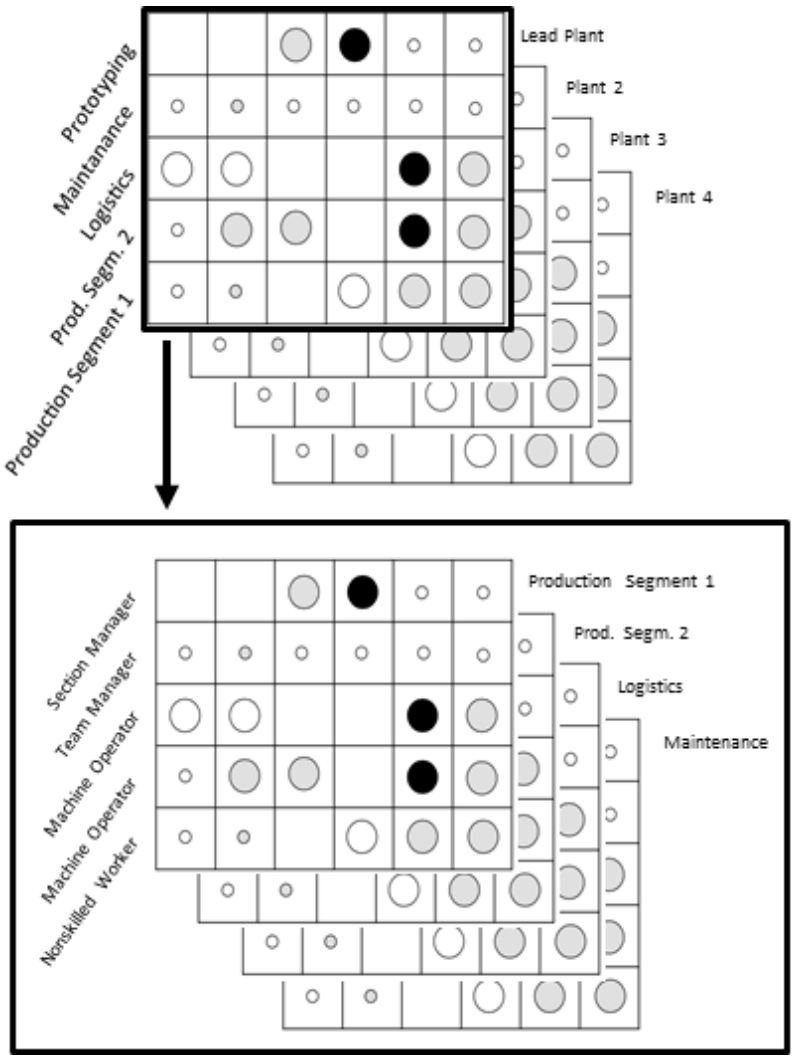

Figure 4. Deriving the detailed qualification matrices for each unit.

the enterprise, this is a multi-stage process. Its procedure is demonstrated by the way of the example in Figure 4.

\section{CONCLUSION AND FURTHER WORK}

In fostering SWLP in manufacturing companies, the activities of Lernfabrik are going to focus on the following issues:

- Development of educational resources, specifically elearning tools, 
- Research on framework conditions for teaching and learning in enterprises

- Research on fostering personal development strategies as required, in keeping with continuous professional development

- Development of methods and tools for effective evaluation of the education process.

The process of technology identification and the planning of training measures is challenging, particularly for small companies. Painstaking practical experience indicates that, above all, the lack of academic personnel, as well as the fast-changing organizational structures, hinder a systematical and strategic procedure. Nonetheless, the above-described processes provide orientation to the management, even in small companies. This especially concerns the use of educational principles, approaches, and methods.

\section{REFERENCES}

[1] O. Cann, Five Million Jobs by 2020: the Real Challenge of the Fourth Industrial Revolution. Available: http://reports.weforum.org/future-of-jobs-2016/press-releases/ (2016, Jan. 22).

[2] M. I. Wolter, A. Mönnig, M. Hummel, C. Scheemann, E. Weber, G. Zika, R. Helmrich, T. Maier, and C. Neuber-Pohl, "Industrie 4.0 und die Folgen für Arbeitsmarkt und Wirtschaft: SzenarioRechnungen im Rahmen der BIBB-IAB-Qualifikations- und Berufsfeldprojektionen," IAB-Forschungsbericht, Aug. 2015.

[3] C. B. Frey and M. A. Osborne, The future of employment: How susceptible are jobs to computerisation? Available: http://www.futuretech.ox.ac.uk/sites/futuretech.ox.ac.uk/files/The Future of Employment OMS Working Paper 1.pdf (2016, Feb. 08).

[4] H. Lasi, H.-G. P. Fettke, T. Kemper, Feld M, and M. Hoffmann, "Industrie 4.0: Bedarfssog und Technologiedruck als Treiber der vierten industriellen Revolution," Wirtschaftsinformatik, vol. 56, no. 4, pp. 261-264, 2014. http://dx.doi.org/10.1007/s11576-0140424-4

[5] P. C. Evans and M. Annunziata, Industrial Internet: Pushing the Boundaries of Minds and Machines. Available: http://www.ge.com/docs/chapters/Industrial_Internet.pdf (2015, Feb. 12).

[6] D. Zuehlke, "SmartFactory-Towards a factory-of-things," Annual Reviews in Control, vol. 34, no. 1, pp. 129-138, 2010. http://dx.doi.org/10.1016/j.arcontrol.2010.02.008

[7] M. A. Schilling, Strategic management of technological innovation, 4th ed.: McGraw-Hill, 2013.

[8] G. Schuh and S. Klappert, Technologiemanagement: Springer, 2010.

[9] R. Rohrbeck, "Harnessing a network of experts for competitive advantage: Technology scouting in the ICT industry," R\&D Management, vol. 40, no. 2, pp. 169-180, 2010. http://dx.doi.org/10.1111/j.1467-9310.2010.00601.x

[10] M. R. Wolff, "Scouting for technology," Technology Management, vol. 35, no. 2, pp. 10-12, 1992.

[11] G. Schuh, T. Gartzen, T. Rodenhäusler, and A. Marks, "Promotion work-based learning through Industry 4.0," Proceeding of the 5th Conference on Learning Factories 2015, pp. 82-87, 2015.

[12] Wuttke, C,C, S. Gärtner, and T. Ackbarow, "Kundenorientierte Entwicklung von Dienstleistungen - ziel- und risikoadäquates Methodenportfolio zur Einbindung von Kunden in die Gestaltung von Dienstleistungen (en: Customer involvement in the development of services using a goal- and risc-oriented composition of specific methods)," Industrie Management, vol. 32, no. 1, pp. 19-24, 2016.

[13] S. Gärtner, "Systematische Kundenintegration bei der Entwicklung industrieller Dienstleistungen (en: Systematical integration in the development of industrial services)," Karlsruher Hochschulschriften, no. 4, 2015.
[14] European Centre for the Development of Vocational Training, Learning and innovation in enterprises, Research Paper. Luxemburg: Publications Office of the European Union,, vol. 27.

[15] European Centre for the Development of Vocational Training, Learning while working: Success stories on workplace learning in Europe. Luxemburg: Publications Office of the European Union,.

[16] K. Kornwachs, "A formal theory of technology?," in Technikphilosophie, Bd. 5, Advances and problems in the philosophy of technology, H. Lenk and M. Maring, Eds, Münster: Lit, 2001, pp. 5165.

[17] A. Grunwald, "Philosophy and the concept of technology - On the anthropological significance of technology," in Wissenschaftsethik und Technikfolgenbeurteilung, Bd. 15, On human nature: Anthropological, biological, and philosophical foundations, A. Grunwald, M. Gutmann, and E. M. Neumann-Held, Eds, Berlin, New York: Springer, 2002, pp. 179-194. http://dx.doi.org/10.1007/9783-642-50023-7_13

[18] W. Schmayl, Pädagogik und Technik: Untersuchungen zum Problem technischer Bildung. Bad Heilbrunn: Klinkhardt, 1989.

[19] W. Kosack, Bildung, Technik und Rationalität: Elemente zur Bildung angesichts der Probleme im technischen Zeitalter. Hamburg: Kovac, 1999.

[20] B. Sachs, "Ansätze allgemeiner technischer Bildung in Deutschland," Zeitschrift für Technik im Unterricht, no. 63/1, pp. 5-13, 1992.

[21] W. Schlagenhauf, "Allgemeine Technische Bildung: Grundzüge, derzeitiger Stand und Entwicklungsperspektiven," in vol. 150, ein/fach Technik: Plädoyers zur technischen Bildung für alle, Verein der Förderer der Schulhefte, Ed, Innsbruck: Studien Verlag, 2013, pp. 17-33.

[22] W. Schmayl, Didaktik allgemeinbildenden Technikunterrichts. Baltmannsweiler: Schneider-Verl. Hohengehren, 2010.

[23] W. Schmayl and F. Wilkening, Eds, Technikunterricht, 2nd ed. Bad Heilbrunn: Klinkhardt, 1995.

[24] C. Wiesmüller, Schule und Technik: Die Schule im schultheoretischen Denken. Baltmannsweiler: Schneider Verlag Hohengehren, 2006.

[25] U. Maxisch, "Nachwuchsbarometer Technikwissenschaften," München, Düsseldorf, 2009.

[26] O. Renn and U. Pfenning, Eds, Wirtschafts- und Technikbildung auf dem Prüfstand.: Zum Fachkräftemangel und zur Attraktivität der MINT-Bildung und -Berufe im europäischen Vergleich.: Nemos, 2012.

[27] M. K. Smith, Informal, non-formal and formal education: a brief overview of different approaches', the encyclopedia of informal education. Available: http://www.infed.org/foundations/informal_nonformal.htm (2016, Feb. 08).

[28] H. Seipel, "Spezifika der sonstigen beruflichen Weiterbildung," in Whitepaper Open Educational Resources (OER) in Weiterbildung/Erwachsenenbildung: Bestandsaufnahme und Potenziale 2015, Bertelsmann Stiftung, Internet \& Gesellschaft Co:llaboratory, MinD-Stiftung, Open Knowledge Foundation Deutschland und Technolog, Ed, 2015, pp. 33-36.

[29] F. Wilkening, "Methoden," in Technikunterricht, W. Schmayl and F. Wilkening, Eds. 2nd ed, Bad Heilbrunn: Klinkhardt, 1995, pp. 145-166.

[30] D. Ifenthaler and M. Gosper, "Research-based learning: Connecting research and instruction," in Curriculum models for the 21st century: Using learning technologies in higher education, $\mathrm{M}$. Gosper and D. Ifenthaler, Eds.: Springer, 2014, pp. 73-89.

[31] M. Jeretin-Kopf, W. Kosack, and C. Wiesmüller, "Technikdidaktische Methoden - Einfluss verschiedener technik-didaktischer Methoden auf die kindliche Motivation und technik-spezifische Denk- und Handlungsweisen," in vol. 7, Wissenschaftliche Untersuchungen zur Arbeit der Stiftung "Haus der kleinen Forscher", Stiftung Haus der kleinen Forscher, Ed, Schaffhausen: Schubi Lernmedien AG, 2015, pp. 250-284.

[32] C. Algeo, "How do they know what you know: A study of knowledge exchange when managing projects," Paper presented at the Australian and New Zealand Academy of Management. Quenstown, NZ, 2015. 
[33] M. Gosper and D. Ifenthaler, Eds, Curriculum models for the 21st century: Using learning technologies in higher education: Springer, 2014. http://dx.doi.org/10.1007/978-1-4614-7366-4

[34] M. A. Runco and R. S. Albert, "Creativity research: A historical view," in Cambridge handbooks in psychology, The Cambridge Handbook of Creativity, J. C. Kaufman and R. J. Sternberg, Eds, Cambridge, New York: Cambridge University Press, 2010, pp. 319. http://dx.doi.org/10.1017/cbo9780511763205.003

[35] R. K. Sawyer, Explaining creativity: The science of human innovation, 2nd ed. New York: Oxford University Press, 2012.

[36] K. A. Heller, "The Munich model of giftedness and talent," in Talentförderung - Expertiseentwicklung - Leistungsexzellenz, vol. 6, Munich studies of giftedness, K. A. Heller, Ed, Berlin, Münster: Lit, 2010, pp. 3-12.

[37] K. Heller, Von der Aktivierung der Begabungsreserven zur Hochbegabtenförderung: Forschungsergebnisse aus vier Dekaden. Berlin: Lit, 2008.

[38] M. Jeretin-Kopf and W. Kosack, "Technische Kreativität," in Entdeckendes Lernen: Ein Unterrichtsprinzip, S. Liebig, Ed, Baltmannsweiler: Schneider Verlag Hohengehren, 2012, pp. 109123.

[39] R. Pittschellis, "Multimedia support for learning factories," Proceeding of the 5th Conference on Learning Factories 2015, pp. 36-40, 2015. http://dx.doi.org/10.1016/j.procir.2015.06.001

\section{AUTHORS}

Maja Jeretin-Kopf is project manager of "Lernfabrik 4.X" at the University of Applied Sciences Karlsruhe, Germany, and associate professor at the University of Education Karlsruhe, Germany. (e-mail: maja.jeretinkopf@hs-karlsruhe.de ).

Claas Christian Wuttke is professor of Logistics and Production Engineering at the Faculty of Management and Engineering of the University of Applied Science Karlsruhe, Germany (e-mail: claas-christian.wuttke@hskarlsruhe.de).

Rüdiger Haas is managing director of Institute of Materials and Processes at the University of Applied Sciences Karlsruhe, Germany, and director of Steinbeis Institute for Transfer Technologies and Integrated Systems (e-mail: ruediger.haas@hs-karlsruhe.de).

Christian Wiesmüller is director of department for technology education at the University of Education Karlsruhe, Germany, and the president of "Deutsche Gesellschaft für Technische Bildung" (e-mail: christian.wiesmueller@ph-karlsruhe.de).

Submitted 19 April 2016. Published as resubmitted by the authors 22 June 2016. 